\title{
PENGARUH ROA, ROE, TOTAL REVENUE, DAN BI RATE TERHADAP SAHAM PADA SEKTOR TRANSPORTASI TAHUN 2009-2014
}

\author{
Devinta Nur Arumsari \\ David Kaluge \\ Program Pascasarjana Ilmu Ekonomi Universitas Brawijaya \\ Jalan Veteran, Malang, Jawa Timur 65145 \\ e-mail: adevinta75@yahoo.com ${ }^{1}$ \\ dkaluge@gmail.com $^{2}$
}

\begin{abstract}
This research aims to test the influence of ROA, ROE, The Total Revenue and the BI rate towards the transport sector stocks. The sample of this research is the transportation company registered in BEI in 2009-2014 and is chosen by the method of random sampling. The data used are the panel data with secondary data typescollected by the method documentation. Hypothesis testing is done by the method of multiple regression analysis that views of $R$-Squared with e-views program results showed that ROA, ROE, Total Revenue doesn't have a significant influence on the price of the shares, while BI Rate has a significant influence on the price of the stock. This research contributes to the development of the capital market in particularscience-related stock price.
\end{abstract}

Key words: ROA, ROE, Total Revenue, BI Rate and stock price 


\section{PENDAHULUAN}

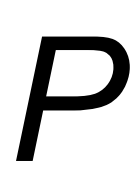

asar modal saat ini sudah banyak diminati oleh beberapa negara untuk menghadapi krisis global khususnya krisis financial. Pasar modal adalah sarana untuk menambahkan dana bagi perusahaan yang membutuhkan dana. Baik individu maupun perusahaan data menambahkan dana atau modalnya yaitu berupa sekuritas ke berbagai perusahaan yang nantinya mendapatkan keuntungan dari perusahaan tersebut. Hal ini dapat disebut dengan investasi. Pengertian saham menurut Hanafi dan Halim (2009:6) adalah bukti kepemilikan suatu perusahaan. Dengan memiliki saham suatu perusahaan, maka investor akan mempunyai hak terhadap pendapatan dan kekayaan perusahaan, setelah dikurangi dengan pembayaran semua kewajiban perusahaan.

Saham merupakan sekuritas yang memberikan penghasilan yang tidak tetap bagi pemiliknya. Pemilik saham akan menerima penghasilan dalam bentuk deviden dan perubahan harga saham. Kalau harga saham meningkat dari harga beli, maka pemodal dikatakan memperoleh capital gain dan apabila sebaliknya maka disebut sebagai capital loss (Tandelilin, 2010:32). Menurut Jogiyanto (2010:111) ada dua jenis saham yang sering diterbitkan oleh perusahaan yaitu:

a. Saham Preferen atau Preferred Stock, merupakan saham yang mempunyai sifat gabungan antara obligasi (bond) dan saham biasa. Seperti bond yang membayarkan bunga atas pinjaman, saham preferen juga memberikan hasil yang tetap berupa deviden preferen. Seperti saham biasa, dalam likuidasi klaim pemegang saham preferen di bawah klaim pemegang bond. Dibandingkan dengan saham biasa, saham preferen mempunyai beberapa hak yaitu hak atas deviden tetap dan hak pembayaran terlebih dahulu jika terjadi likuidasi.

b. Saham biasa atau Common Stock Saham biasa atau Common Stock, adalah sertifikat yang menunjukkan buku kepemilikan suatu perusahaan. Jika perusahaan hanya mengeluarkan satu kelas saham saja, maka saham tersebut biasanya dalam bentuk saham biasa atau common stock

Handoko (2008), melakukan penelitian pada perusahaan yang tergabung dalam indeks LQ 45 di BEI periode 2003-2005 dengan menguji pengaruh variabel EVA, ROA, ROE, EPS terhadap perubahan harga saham. Hasilnya

QE Journal | Vol.04 - No.03 September 2015 - 144 
dapat disimpulkan bahwa secara serentak variabel EVA, ROE, ROA dan EPS berpengaruh signifikan terhadap perubahan harga saham. Secara parsial hanya variabel EPS yang berpengaruh secara signifikan terhadap perubahan harga saham, sedangkan variabel EVA, ROE, dan ROA tidak berpengaruh signifikan terhadap perubahan harga saham. Penelitian yang dilakukan oleh Wijaya dan Tjun (2009) yang mengambil sampel perusahaan yang tergabung dalam indeks LQ 45 di BEI sampai dengan 31 Desember 2007 telah menguji variabel EVA terhadap return saham. Hasilnya adalah EVA mempunyai pengaruh signifikan terhadap return saham.

Menurut data yang dapat dihimpun dari Badan Koordinasi Penanaman Modal (BKPM), untuk Penanaman Modal Asing (PMA) investasi yang mendominasi adalah sektor transportasi, gudang dan telekomunikasi dengan pencapaian investasi sebesar US\$ 3,8 miliar. Hal ini menunjukkan bahwa sektor transportasi dipandang memiliki prospek yang cukup bagus di masa mendatang. Subsektor transportasi merupakan subsektor yang cukup komplek, karena terdiri dari beberapa kegiatan diantaranya transportasi darat (angkutan kereta api, lalu lintas angkutan jalan dan angkutan sungai danau serta penyebrangan), transportasi laut, transportasi udara, dan jasa penunjang angkutan. Dengan banyaknya kegiatan dalam subsector transportasi ini memberikan dampak terhadap fluktuasi harga sahamnya.

Berdasarkan latar belakang, penulis memberikan rumusan masalah mengenai apakah profitabilitas ROA, ROE, total revenue merupakan faktor yang mempengaruhi harga saham? Dan Apakah BI Rate merupakan faktor yang mempengaruhi harga saham? Tujuan dilakukannya penelitian ini adalah untuk menganalisis dengan menggunakan APT apakah profitabilitas merupakan faktor yang mempengaruhi harga saham sektor transportasi. Dan menganalisis dengan menggunakan APT apakah BI Rate merupakan faktor yang mempengaruhi harga saham sektoral di Indonesia.

Dalam studi ini yang dimaksu ROA merupakan rasio untuk mengukur kemampuan manajemen dalam mengelola asetnya untuk menghasilkan income dari pengelolaan asset (Kasmir, 2012:329). Semakin besar ROA yang diperoleh, semakin besar pula tingkat keuntungan yang dicapai oleh perusahaan tersebut dan semakin baik pula posisi perusahaan tersebut dari segi penggunaan asset. Sedangkan ROE merupakan rasio untuk mengukur 
kemampuan manajemen bank dalam mengelola kapital yang ada untuk mendapatkan net income (Kasmir, 2012: 328). Semakin tinggi ROE berarti semakin baik kinerja perusahaan dalam mengelola modalnya untuk menghasilkan keutungan bagi pemegang saham. Kemudian penerimaan atau revenue adalah semua penerimaan produsen dari hasil penjualan barang atau outputnya. Macam-macam revenue adalah: Total revenue adalah penerimaan total dan hasil penjualan output, Average revenue adalah penerimaan per unti dari penjualan output, Marginal revenue adalah kenaikan atau penurunan penerimaan sebagai akibat dari penambahan atau pengurangan satu unit output. Dan suku bunga dapat didefinisikan sebagai tingkat pengembalian aset yang mempunyai risiko mendekati nol. Peningkatan suku bunga membuat nilai imbal hasil dari deposito dan obligasi menjadi lebih menarik, sehingga banyak investor pasar modal yang mengalihkan portofolio sahamnya. Meningkatnya aksi jual dan minimnya permintaan akan menurunkan harga saham dan sebaliknya (Prastowo, 2008:9). Perusahaan dalam operasional perusahaan, akan menghadapi risiko suku bunga terutama timbul terutama dari pinjaman untuk tujuan modal kerja dan investasi. Suku bunga dalam penelitian ini diukur menggunakan sensitivitas perusahaan terhadap suku bunga. kinerja keuangan yang diwakili oleh rasio-rasio.

Kebutuhan akan informasi yang lebih lengkap tentang bursa semakin meningkat, salah satu informasi yang dibutuhkan adalah indeks harga saham sebagai cerminan dari pergerakan harga saham. Di pasar modal, sebuah indeks diharapkan memiliki lima fungsi, yaitu: (1) sebagai indikator trend pasar, (2) sebagai indikator tingkat keuntungan, (3) sebagai tolak ukur kinerja suatu portofolio, (4) memfasilitasi pembentukan portofolio dengan strategi pasif, dan (5) memfasilitasi berkembangnya produk derivatif.

ROA merupakan rasio untuk mengukur kemampuan manajemen dalam mengelola asetnya untuk menghasilkan income dari pengelolaan asset (Kasmir, 2012:329). Semakin besar ROA yang diperoleh, semakin besar pula tingkat keuntungan yang dicapai oleh perusahaan tersebut dan semakin baik pula posisi perusahaan tersebut dari segi penggunaan asset. Penelitian untuk melihat pengaruh variabel return on assets (ROA) dengan harga saham perusahaan telah banyak dilakukan sebelumnya. Hasil penelitian sebelumnya menunjukkan bahwa variabel ROA memiliki 
pengaruh terhadap harga saham Kusumawardani, 2011; Abigael dan Ika, 2008; Rahmi, et al., 2013; Yanti dan Safitri, 2013; dan Ghozali, 2013). Namun beberapa penelitian sebelumnya menunjukkan bahwa variable ROA tidak memiliki pengaruh terhadap harga saham (Utami dan Rahayu, 2003; Setianingrum, 2009; Stella, 2009; Pontoh, 2009; Wahyuni, 2012; Safitri ,2013; Itabillah, 2013; Machfiro dan Sukoharsono, 2013). Berdasarkan hasil penelitian sebelumnya menunjukkan adanya inkonsistensi hasil penelitian.

Menurut Mardiyanto (2009:196) ROE adalah rasio yang digunakan untuk mengukur keberhasilan perusahaan dalam menghasilkan laba bagi para pemegang saham. ROE dianggap sebagai representasi dari kekayaan pemegang saham atau nilai perusahaan. Return on equity (ROE) adalah perbandingan antara laba bersih dengan ekuitas. Rasio ini memberikan ukuran tingkat hasil pengembalian atas investasi bagi pemegang saham. Return on equity (ROE) adalah perbandingan antara laba bersih dengan ekuitas. Rasio ini memberikan ukuran tingkat hasil pengembalian atas investasi bagi pemegang saham. Menurut Tandelilin (2001:48), sumbersumber return investasi terdiri dari dua komponen, yaitu yield dan capital gain (loss). Risiko dan return mempunyai hubungan positif, semakin tinggi risiko semakin tinggi return yang dihasilkan, begitu pula sebaliknya (Hartono, 2003:144).

Penerimaan atau revenue adalah semua penerimaan produsen dari hasil penjualan barang atau outputnya. Pada pasar persaingan sempurna, TR merupakan garis lurus dari titik origin, karena harga yang terjadi dipasar bagi mereka merupakan suatu datum (tidak bisa dipengaruhi), maka penerimaan mereka naik sebanding (proporsional) dengan jumlah barang yang di jual. Pada pasar peraingan tidak sempurna, TR merupakan garis melengkung dari titik origin, karena masing perusahaan dapat menentukan sendiri harga barang yang dijualnya, dimana mula-mula TR naik sangat cepat, (akibat pengaruh monopoli) kemudian pada titik tertentu mulai menurun (akibat pengaruh persaingan dan substansi). Implikasi dari pendekatan totalitas adalah perusahaan menempuh strategi penjualan maksimal (maximum selling). Sebab semakin besar penjualan makin besar laba yang diperoleh. Hanya saja sebelum mengambil keputusan, perusahaan harus menghitung berapa unit output yang harus diproduksi untuk mencapai titik impas. Kemudian besarnya output tadi dibandingkan dengan potensi permintaan efektif. 
BI rate adalah suku bunga kebijakan yang mencerminkan sikap atau stance kebijakan moneter yang ditetapkan oleh bank Indonesia dan diumumkan kepada publik. BI rate diumumkan oleh Dewan Gubernur Bank Indonesia setiap Rapat Dewan Gubernur bulanan dan diimplementasikan pada operasi moneter yang dilakukan Bank Indonesia melalui pengelolaan likuiditas (liquidity management) di pasar uang untuk mencapai sasaran operasional kebijakan moneter.

Sejak awal Juli 2005, Bank Indonesia (BI) menggunakan mekanisme "BI rate" (suku bunga BI), yaitu BI mengumumkan target suku bunga SBI yang diinginkan BI untuk pelelangan pada masa periode tertentu. BI rate ini kemudian yang digunakan sebagai acuan para pelaku pasar dalam mengikuti pelelangan. Sehingga kebijaksanaan pengenaan suku bunga yang dilakukan oleh Bank Indonesia (BI) tersebut pada awalnya hanya diberikan sebagai pedoman saja untuk bank - bank umum pemerintah, namun kemudian dijadikan juga sebagai landasan bagi bank - bank swasta.

\section{METODE PENELITIAN}

Penelitian ini dilaksanakan di malang dengan cara mengambil data terkait yang terdapat di BEI, Bank Indonesia, Yahoo Finance serta Biro Pusat Statistik Indonesia. Penelitian dilaksanakan dari bulan Desember 2015 sampai dengan januari 2016, dengan data rentang waktu yang di ambil adalah tahun 2009 sampai dengan tahun 2014.

Jenis data yang digunakan dalam penelitian ini adalah data sekunder yang meliputi data ROA, ROE, Total Revenue dan BI Rate terhadap Harga Saham.

Data bersumber dari Yahoo!Finance (www.finance.yahoo.com). Biro Pusat Statistik (BPS) Indonesia, Bank Indonesia (www.bi.go.id) dan (Sahamok.com) Semua data yang diambil merupakan periode tahunan dari 2009 sampai dengan 2014

\section{Pengolahan Data Saham dan Indikator Ekonomi}

Pada penelitian ini, digunakan alat bantu perangkat lunak Eviews versi 6.0. Dalam metode estimasi model regresi dengan menggunakan data panel dapat dilakukan melalui tiga pendekatan, antara lain: 


\section{Common Effect Model / Pooled Least Square (PLS)}

Merupakan pendekatan model data panel yang paling sederhana karena hanya mengkombinasikan data time series dan cross section. Pada model ini tidak diperhatikan dimensi waktu maupun individu, sehingga diasumsikan bahwa perilaku data perusahaan sama dalam berbagai kurun waktu. Metode ini bisa menggunakan pendekatan Ordinary Least Square (OLS).

\section{Fixed Effect Model}

Model ini mengasumsikan bahwa perbedaan antar individu dapat diakomodasi dari perbedaan intersepnya. Untuk mengestimasi data panel model Fixed Effects menggunakan teknik variable dummy untuk menangkap perbedaan intersep antar data. Model estimasi ini sering juga disebut dengan teknik Least Squares Dummy Variable (LSDV). Metode fixed effect dapat mengatasi hal tersebut karena metode ini memunkinkan adanya perubahan pada setiap i dan $\mathrm{t}$.

Sesungguhnya model fixed effect adalah sama dengan regresi yang menggunakan dummy variable sebagai variabel bebas, sehingga dapat diestimasi dengan model OLS. Oleh sebab itu, model ini juga sering disebut sebagai model Least Square Dummy Variable.

\section{Random Effect Model}

Model ini akan mengestimasi data panel dimana variabel gangguan mungkin saling berhubungan antar waktu dan antar individu. Pada model Random Effect perbedaan intersep diakomodasi oleh error terms masingmasing. Keuntungan menggunkan model Random Effect yakni menghilangkan heteroskedastisitas. Model ini juga disebut dengan Error Component Model (ECM) atau teknik Generalized Least Square (GLS). Dapat dinyatakan bahwa model random effect menganggap efek rata-rata dari data cross section dan time series direpresentasikan dalam intercept.

\section{Pemilihan Spesifikasi Model Terbaik}

Terdapat tiga macam pendekatan dalam metode analisa yang bisa digunakan dalam analisis regresi data panel, yaitu model Common Effect, model efek tetap (Fixed Effect), dan model efek acak (Random Effect). Untuk memilih salah satu model estimasi yang dianggap paling tepat dari tiga jenis model data panel, maka perlu dilakukan serangkaian uji, yaitu: 
1) Uji Chow statistik digunakan untuk menentukan metode antara pendekatan common effect dan fixed effect.

2) Uji Hausman digunakan untuk menentukan metode antara pendekatan random effect dan fixed effect.

Pemilihan antara Common Effect Model dengan Fixed Effect Model (Uji Chow)

(Uji F Statistik) Pemilihan antara Common Effect dengan Fixed Effect Keputusan pemilihan model yang digunakan antara common effect dengan fixed effect dapat menggunakan Chow Test. Dalam pengujian ini dilakukan dengan hipotesa sebagai berikut:

Ho: $\beta 1=0$ (model common effect)

$\mathrm{H} 1: \beta 1 \neq 0$ (model fixed effect)

Hipotesis nolnya adalah intersep dan slope (common effect). Nilai statistik hitung hingga akan mengikuti distribusi statistik $\mathrm{F}$ dengan derajat bebas (df) sebanyak m untuk numerator dan $(\mathrm{n}-\mathrm{k})$ untuk denumerator. Jika nilai Chow Statistic (F Stat) > F Tabel, maka cukup bukti untuk melakukan penolakan terhadap hipotesa nol sehingga model yang digunakan adalah model fixed effect, begitu juga sebaliknya.

\section{Koefisien Determinasi $\left(\mathbf{R}^{2}\right)$}

Koefisien determinasi $\left(R^{2}\right)$ pada intinya mengukur seberapa jauh kemampuan model dalam menerangkan variasi variabel-variabel dependen. Nilai koefisien determinasi adalah antara nol sampai satu. Nilai $\left(R^{2}\right)$ yang kecil berarti kemampuan variabel-variabel independen dalam menjelaskan variasi variabel dependen amat terbatas.

Koefisien determinasi digunakan untuk mengukur persentase variasi variabel terikat yang dijelaskan oleh semua variabel bebasnya. Nilai koefisien determinasi terletak antara 0 dan $1(0<R 2<1)$, dimana semakin tinggi nilai R2 suatu regresi atau semakin mendekati 1, maka hasil regresi tersebut akan semakin baik. Hal ini berarti bahwa keseluruhan variabel bebas secara bersama-sama mampu menerangkan variabel terikatnya, dalam Hendrawan (2013).

Besaran $\mathrm{R}^{2}$ terletak antara 0 dan 1 , jika $\mathrm{R}^{2}=1$ berarti bahwa semua variasi dalam variabel tak bebas $\mathrm{Y}$ dapat dijelaskan oleh variabel-variabel bebas $\mathrm{X}$

QE Journal | Vol.04 - No.03 September 2015 - 150 
yang digunakan dalam model regresi sebesar $100 \%$. Jika $\mathrm{R}^{2}=0$ berarti tidak ada variasi dalam variabel tak bebas $Y$ yang dapat dijelaskan oleh variabelvariabel bebas X. Model dikatakan baik jika $\mathrm{R}^{2}$ mendekati 1 .

\section{HASIL DAN PEMBAHASAN}

Uji spesifikasi model yang pertama dilakukan dengan menggunakan Uji Chow (Chow Test) untuk menguji apakah lebih baik menggunakan common effect atau fixed effects. Dengan total data sebanyak 30 observasi. Criteria pengambilan keputusan yaitu apabila:

1. Probability ( $\mathrm{p}$-value) Cross-section Chi-square $<0,05=$ tolak Ho

2. Probability ( $\mathrm{p}$-value) Cross-section Chi-square $>0,05=$ terima Ho atau

1. Probability ( $\mathrm{p}$-value) Cross-section $\mathrm{F}<0,05=$ tolak Ho

2. Probability ( $\mathrm{p}$-value) Cross-section $\mathrm{F}>0,05=$ terima Ho

Berikut tabel hasil uji Chow dari regresi data panel yang peneliti lakukan. 


\section{Hasil Uji Chow Test}

Redundant Fixed Effects Tests

Pool: DEV

Test cross-section fixed effects

\begin{tabular}{lcrc}
\hline \hline Effects Test & Statistic & d.f. & Prob. \\
\hline \hline Cross-section F & 2.029347 & $(4,21)$ & 0.1270 \\
Cross-section Chi-square & 9.804394 & 4 & 0.0439 \\
\hline \hline
\end{tabular}

Cross-section fixed effects test equation:

Dependent Variable: HARGA_SAHAM?

Method: Panel Least Squares

Date: 12/27/15 Time: 21:06

Sample: 20092014

Included observations: 6

Cross-sections included: 5

Total pool (balanced) observations: 30

\begin{tabular}{lrccc}
\hline \hline \multicolumn{1}{c}{ Variable } & Coefficient & Std. Error & t-Statistic & Prob. \\
\hline \hline C & -1136.262 & 681.9550 & -1.666183 & 0.1082 \\
ROA? & -0.053505 & 0.293209 & -0.182483 & 0.8567 \\
ROE? & -0.056002 & 0.187906 & -0.298030 & 0.7681 \\
$\quad$ REVENUE? & 0.000197 & 0.000395 & 0.498497 & 0.6225 \\
$\quad$ BI_RATE? & 204.8662 & 98.77322 & 2.074107 & 0.0485 \\
\hline \hline R-squared & 0.161839 & Mean dependent var & \multirow{2}{*}{272.2610} \\
Adjusted R-squared & 0.027734 & S.D. dependent var & 405.9696 \\
S.E. of regression & 400.3004 & Akaike info criterion & 14.97332 \\
Sum squared resid & 4006011. & Schwarz criterion & 15.20685 \\
Log likelihood & -219.5998 & Hannan-Quinn criter. & 15.04803 \\
F-statistic & 1.206806 & Durbin-Watson stat & 1.240729 \\
Prob(F-statistic) & 0.332680 & & \\
\hline \hline
\end{tabular}

Dari hasil chow test diatas, dapat dilihat bahwa nilai probabilitas chisquarenya lebih besar dari $\alpha(0,000<0,05)$ sehingga H0 ditolak dan H1 diterima yang berarti model yang paling tepat untuk digunakan adalah Fixed Effect Model (FEM). Uji spesifikasi model tidak terhenti pada chow 
test yang menyimpulkan bahwa fixed effect lebih baik. Namun, diperlukan Haussman Test untuk menguji manakah yang lebih tepat menggunakan model fixed effect atau random effect.

\section{Uji Housman test}

Model random effect menggnakan residual yang diduga memiliki hubungan antar waktu dan antar individu/antar perusahaan. Untuk mengji model ini dilakukan dengan Housman test untuk menentukan apakah model random (Ho) atau Fixed (H1) yang akan di gunakan utnuk regres data panel pada penelitian ini.

Correlated Random Effects - Hausman Test

Pool: DEV

Test cross-section random effects

\begin{tabular}{llrr}
\hline \hline Test Summary & $\begin{array}{c}\text { Chi-Sq. } \\
\text { Statistic }\end{array}$ & Chi-Sq. d.f. & Prob. \\
\hline \hline Cross-section random & 0.000000 & 4 & 1.0000 \\
\hline \hline
\end{tabular}

${ }^{*}$ Cross-section test variance is invalid. Hausman statistic set to zero.

Cross-section random effects test comparisons:

\begin{tabular}{crrrr} 
Variable & Fixed & Random & Var(Diff.) & Prob. \\
\hline \hline ROA? & -0.059427 & -0.058971 & 0.002994 & 0.9933 \\
ROE? & 0.034874 & 0.016981 & 0.002993 & 0.7436 \\
REVENUE? & 0.000134 & 0.000145 & 0.000000 & 0.9401 \\
BI_RATE? & 202.631943 & 203.057644 & 0.662189 & 0.6009 \\
\hline \hline
\end{tabular}

Cross-section random effects test equation:

Dependent Variable: HARGA_SAHAM?

Method: Panel Least Squares

Date: 12/27/15 Time: 21:07

Sample: 20092014

Included observations: 6

Cross-sections included: 5

Total pool (balanced) observations: 30

QE Journal | Vol.04 - No.03 September 2015 - 153 


\begin{tabular}{|c|c|c|c|c|}
\hline Variable & Coefficient & Std. Error & t-Statistic & Prob. \\
\hline C & -1130.937 & 633.8181 & -1.784324 & 0.0888 \\
\hline ROA? & -0.059427 & 0.289970 & -0.204941 & 0.8396 \\
\hline ROE? & 0.034874 & 0.204634 & 0.170421 & 0.8663 \\
\hline REVENUE? & 0.000134 & 0.000457 & 0.293707 & 0.7719 \\
\hline BI_RATE? & 202.6319 & 91.54028 & 2.213582 & 0.0381 \\
\hline \multicolumn{5}{|c|}{ Effects Specification } \\
\hline \multicolumn{5}{|c|}{ Cross-section fixed (dummy variables) } \\
\hline R-squared & 0.395503 & Mean dependent var & & 272.2610 \\
\hline Adjusted R-squared & 0.165219 & S.D. dependent var & & 405.9696 \\
\hline S.E. of regression & 370.9197 & Akaike info criterion & & 14.91317 \\
\hline Sum squared resid & 2889209. & Schwarz criterion & & 15.33353 \\
\hline Log likelihood & -214.6976 & Hannan-Quinn criter. & & 15.04765 \\
\hline F-statistic & 1.717454 & Durbin-Watson stat & & 1.705723 \\
\hline Prob(F-statistic) & 0.152780 & & & \\
\hline
\end{tabular}

Haussman Test adalah pengujian yang dilakukan untuk memilih model antara FEM dan REM, manakah yang paling tepat digunakan. Hipotesis untuk Haussman test adalah :

$$
\begin{aligned}
& \mathrm{H} 0=\mathrm{REM} \\
& \mathrm{H} 1=\mathrm{FEM}
\end{aligned}
$$

Dari hasil diatas, dapat dilihat bahwa nilai $p$-value sebesar 1.000 lebih besar dari $\alpha$ yaitu sebebsar 0.05 , sehingga kesimpulannya model yang akan digunakan dalam regresi panel dalam penelitian ini adalah model random effect (REM). Pengujian panel data dengan efek acak (random effect) diasumsikan bahwa komponen error individual tidak berkorelasi antara satu dengan lainnya dan tidak ada autokorelasi antar individu (cros section) maupun antar waktu (time series).Kedua variabel random tersebut, yaitu variabel cross section dan time series, diasumsikan terdistribusi normal dengan derajat bebas yang tidak berkurang.

\section{Uji Hipotesis}

Dari hasil pengujian spesifikasi model, di dapatkan bahwa model yang paling tepat untuk digunakan adalah Random Effect Model (REM).proses selanjutnya adalah melakukan evaluasi dan interpretasi untuk mengetahui

QE Journal | Vol.04 - No.03 September 2015 - 154 
seberapa baik hasil regresi yang didapatkan. Karena metode yang terpilih dalam penelitian ini adalah metode random effect maka pengujian hipotesis dilakukan berdasarkan nilai dari hasil regresi pada metode random effect.

\section{Hasil Pengolahan Data Menggunakan Random Effect}

Dependent Variable: HARGA_SAHAM?

Method: Pooled EGLS (Cross-section random effects)

Date: 12/27/15 Time: 21:06

Sample: 20092014

Included observations: 6

Cross-sections included: 5

Total pool (balanced) observations: 30

Swamy and Arora estimator of component variances

\begin{tabular}{crrrr}
\hline \hline Variable & Coefficient & Std. Error & t-Statistic & Prob. \\
\hline \hline C & -1131.674 & 650.9803 & -1.738415 & 0.0944 \\
ROA? & -0.058971 & 0.284762 & -0.207087 & 0.8376 \\
ROE? & 0.016981 & 0.197186 & 0.086118 & 0.9321 \\
REVENUE? & 0.000145 & 0.000433 & 0.335704 & 0.7399 \\
BI_RATE? & 203.0576 & 91.53667 & 2.218320 & 0.0358 \\
Random Effects (Cross) & & & \\
_HITS--C & 122.6053 & & & \\
_IATA--C & -157.3109 & & & \\
_INDX--C & -62.54391 & & & \\
_ZBRA--C & -156.1481 & & & \\
_TMAS--C & 253.3976 & & & \\
\hline \hline
\end{tabular}

\begin{tabular}{lrc}
\hline \hline & & \\
& Effects Specification & \\
& S.D. & Rho \\
\hline \hline Cross-section random & 337.3448 & 0.4527 \\
Idiosyncratic random & 370.9197 & 0.5473 \\
\hline \hline
\end{tabular}

Weighted Statistics

\begin{tabular}{llll}
\hline \hline R-squared & 0.191656 & Mean dependent var & 111.4949 \\
Adjusted R-squared & 0.062322 & S.D. dependent var & 362.6416 \\
S.E. of regression & 351.1597 & Sum squared resid & 3082828. \\
F-statistic & 1.481861 & Durbin-Watson stat & 1.597167 \\
Prob(F-statistic) & 0.237618 & &
\end{tabular}

QE Journal | Vol.04 - No.03 September 2015 - 155 


\begin{tabular}{lcll}
\hline \hline \multicolumn{4}{c}{ Unweighted Statistics } \\
\hline \hline R-squared & 0.155471 & Mean dependent var & 272.2610 \\
Sum squared resid & 4036451. & Durbin-Watson stat & 1.219832 \\
\hline \hline
\end{tabular}

Dependent Variable: HARGA_SAHAM?

Method: Pooled Least Squares

Date: 12/27/15 Time: 21:06

Sample: 20092014

Included observations: 6

Cross-sections included: 5

Total pool (balanced) observations: 30

\begin{tabular}{lrrrr}
\hline \hline \multicolumn{1}{c}{ Variable } & Coefficient & Std. Error & t-Statistic & Prob. \\
\hline \hline \multicolumn{1}{c}{ ROA? } & -0.117965 & 0.300409 & -0.392682 & 0.6978 \\
ROE? & -0.055598 & 0.194218 & -0.286268 & 0.7769 \\
REVENUE? & 0.000203 & 0.000409 & 0.496890 & 0.6234 \\
BI_RATE? & 41.86476 & 14.08062 & 2.973219 & 0.0063 \\
\hline \hline R-squared & 0.068765 & Mean dependent var & 272.2610 \\
Adjusted R-squared & -0.038686 & S.D. dependent var & 405.9696 \\
S.E. of regression & 413.7477 & Akaike info criterion & 15.01196 \\
Sum squared resid & 4450865. & Schwarz criterion & 15.19878 \\
Log likelihood & -221.1793 & Hannan-Quinn criter. & 15.07172 \\
Durbin-Watson stat & 1.100274 & & \\
\hline \hline
\end{tabular}

Berdasarkan hasil output diatas dapat disimpulkan :

1. ROA memiliki nilai t-hitung sebesar 0,392682 dengan tingkat probabilitas sebesar 0.6978 yang berada diatas $\alpha=5 \%$. Karena nilai signifikansi $>\alpha=5 \%$, maka dinyatakan berpengaruh negatif dan tidak signifikan terhadap harga saham

2. ROE memiliki nilai t-hitung $>\alpha=5 \%$, maka dinyatakan bahwa tidak pengaruh positif.

3. Revenue memiliki nilai t-hitung berada diatas $\alpha=5 \%$, maka dinyatakan tidak berpengaruh positif 
4. BI Rate memiliki pengaruh positif sehingga signifikan terhadap harga saham

\section{SIMPULAN DAN SARAN}

\section{Simpulan}

Penelitian ini mencoba untuk menjawab tujuan penelitian, yaitu untuk menganalisis pengaruh Return On Equity (ROE), Return On Asset (ROA), Total Revenue, dan BI Rate terhadap harga saham sektor Transportasi yang terdaftar di Bursa Efek Indonesia Hasil pengujian hipotesis dengan menggunakan model regresi data panel dengan empat variabel independen (Return On Equity (ROE), Return On Asset (ROA), Total Revenue dan satu variabel dependen yaitu harga saham menunjukkan hasil sebagai berikut :

1. Variable ROA, ROE, Total revenue tidak memiliki pengaruh yang signifikan terhadap tingkat harga saham pada perusahaan sektor transportasi

2. Variable BI Rate memiliki pengaruh yang signifikan terhadap tingkat harga saham pada perusahaan sektor transportasi.

\section{Saran}

Saran yang dapat diberikan dari penelitian ini adalah sebagai berikut :

1. Penelitian selanjutnya dapat menambahkan beberapa variabel lain yang mempengaruhi harga saham sebuah perusahaan.

2. Pada penelitian ini, perhitungan variabel independennya lebih banyak berkaitan dengan factor internal, oleh karena itu penulis menyarankan untuk penelitian berikutnya variable independennya lebih dikombinasi misalnya dengan menggunakan variabel Debt to Equity Ratio (DER) dan melibatkan tingkat inflasi serta suku bunga.

\section{DAFTAR PUSTAKA}

Algifari. 2000. Analisis Regresi (Teori, Kasus dan Solusi), Edisi kedua. Yogyakarta: BPFE.

Ang, Robbert. 1997. Buku Pintar: Pasar Modal Indonesia. Edisi Pertama. Jakarta: Media Soft Indonesia.

QE Journal | Vol.04 - No.03 September 2015 - 157 
Anoraga, Panji dan Piji Pikarti. 2001. Pengantar Pasar Modal. Jakarta: Rineka Cipta.

Arikunto, S. 2006. Prosedur Penelitian Suatu Praktek. Jakarta: Rineka Cipta.

Auliah, Robiatul dan Hamzah, Ardi. 2006. Analisa Karakteristik Perusahaan, Industri dan Ekonomi Makro Terhadap Return dan Beta Saham Syariah di Bursa Efek Jakarta. Padang: Simposium Nasional Akuntansi 9.

Bachri, Syamsul. 1997. Profitabilitas dan Nilai Pasar Terhadap Perubahan Harga Saham Pada Perusahaan Go Public di BEJ. Jurnal Persepsi edisi khusus Vol. I.

Mankiw, Gregory. 2003. Teori Makro Ekonomi. Jakarta: Erlangga.

Dhankar, R. dan R. Singh. 2005. Arbitrage Pricing Theory and the Capital Asset Pricing Model - Evidence from the Indian Stock Market. Journal of Financial Management and Analysis 18 (1): 14.

Handoko, Wahyu. 2008. Pengaruh Economic Value Added, ROE, ROA, dan EPS terhadap Perubahan Harga Saham Perusahaan Kategori LQ45 Pada Bursa Efek Jakarta. Skripsi Fakultas Ekonomi, Universitas Muhammadiyah Surakarta: Surakarta.

Hartono, Jogiyanto. 2003. Teori Portofolio dan Analisis Investasi. Edisi Ketujuh, Yogyakarta: BPFE.

------,. 2011. Teori Portofolio dan Analisis Investasi. Edisi Ketujuh, Yogyakarta: BPFE.

Sulastri. 2012. Pengaruh Economic Value Added (EVA) Momentum, ROE, ROA, dan EPS terhadap Perubahan Harga Saham Perusahaan Kategori LQ45 pada Bursa Efek Indonesia. Skripsi (tidak diterbitkan). Fakultas Ekonomi dan Bisnis, Universitas Mercubuana Jakarta.

Sunardi, Hardjono. 2010. Pengaruh Penilaian Kinerja dengan ROI dan EVA terhadap Return Saham pada Perusahaan yang Tergabung dalam Indeks LQ 45 di Bursa Efek Indonesia. Jurnal Akuntansi. Vol.2 No.1, Mei 2010, Hal. 70-92.

Tandelili, Eduardus. 2007. Portofolio dan investasi Teori dan aplikasi. Yogyakarta: Kanisius. 